\title{
Tumpang Tindih Pemanfaatan Sumberdaya Perikanan dengan Pertambangan Timah di Perairan Kota Pangkalpinang, Bangka Belitung
}

\author{
[The Overlapping of Fisheries Resources Utilization with Tin Mining in the \\ Coastal of Pangkalpinang, Bangka Belitung]
}

\author{
Siti Aisyah', Leni Anggeraini ${ }^{2}$, Endang Bidayani ${ }^{3}$, Kurniawan' \\ 1Jurusan Manajemen Sumberdaya Perairan Universitas Bangka Belitung \\ 'Bappeda Kota Pangkalpinang, \\ ${ }^{3}$ Jurusan Akuakultur Universitas Bangka Belitung
}

\begin{abstract}
Abstrak
Wilayah Kepulauan Bangka Belitung memiliki potensi timah yang cukup besar dan dimanfaatkan sejak ratusan tahun lalu sebagai penghasil devisa bagi Indonesia. Lokasi penambangan timah yang menjadi kajian ini yaitu perairan Kota Pangkalpinang. Selain menjadi sumber eksploitasi penambangan timah laut, perairan Kota Pangkalpinang juga dimanfaatkan sumberdayanya dengan kegiatan perikanan tangkap oleh nelayan. Masalah dalam pemanfaatan ganda sumberdaya pesisir adalah ketidakseimbangan pemanfaatan sumberdaya, sehingga berpotensi menimbulkan konflik. Tujuan dari penelitian ini untuk mengetahui dampak penambangan timah di laut dan rekomendasi kebijakan pengelolaan sumberdaya yang tepat di Perairan Kota Pangkalpinang. Metode penelitian ini adalah metode survei dengan analisis deskriptif kualitatif. Pengambilan sampel dengan teknik purposive sampling. Hasil dari penelitian menunjukan bahwa analisis konflik pemanfaatan sumberdaya pesisir terdiri dari empat isu utama meliputi 1) isu lingkungan bahwa kondisi perairan yang mulai tercemar sebagai dampak dari penambangan timah ilegal di laut; 2) penertiban oleh Pemerintah Kota Pangkalpinang terhadap penambangan timah ilegal untuk menegakan aturan; 3) isu sosial layaknya fenomena gunung es yang suatu saat dapat meledak dan menjadi masalah yang berujung konflik, terutama dalam perebutan pemanfaatan sumberdaya pesisir antara nelayan dan penambang timah di laut; dan 4) isu ekonomi, terkait perbedaan pendapatan antara nelayan dan penambang timah menyebabkan kegiatan penambangan sulit ditinggalkan oleh masyarakat, dan berpotensi menjadikan penambang sebagai profesi sampingan bagi sebagian nelayan. Adapun analisis resolusi konflik perlu dilakukan secara harmoni antara pemerintah, masyarakat, swasta, perguruan tinggi dan LSM dengan pendekatan pemahaman kepentingan pelestarian lingkungan, sehingga kebijakan pengelolaan sumberdaya pesisir yang tepat dapat dilakukan.
\end{abstract}

Kata kunci : Pangkalpinang; pertambangan timah; sumberdaya perikanan

\section{Abstract}

Bangka Belitung Islands have considerable tin potential. This potential has become one of the major foreign exchange earners for Indonesia. However, the majority of tin mining activities carried out without permission or illegal and indicated the emergence of various implications for environmental damages. This study focuses on one tin mining location in the coast of Pangkalpinang, one of many tin mining locations in the area. There are two economic activities in the coastal of Pangkalpinang: fishing and tin mining activities. One important problem in the dual utilization of coastal resources is the imbalance in the use of these resources, which has the potential to cause conflicts. The purpose of this study is to determine the impact of tin mining and propose recommendations for appropriate resource management policies in the coastal area of Pangkalpinang. The results of the study show that the conflict analysis of coastal resource use consists of four main issues including a) environmental issues which indicate that the condition of waters that are starting to be polluted and largely caused by the impact of illegal tin mining at the sea; b) law issues, control by the Government of Pangkalpinang against illegal tin mining as 
a form of enforcement of the rules; 3 ) social issues, in the struggle for the utilization of coastal resources between fishermen and tin miners; and 4) economic issues, related to the difference in income between fishermen and tin miners, making mining activities difficult for the community to abandon, and may cause some fishermen to take shift livelihood as tin miners too. The conflict resolution analysis needs to be done in harmony among the local government, the community, the private sectors, local universities and NGO by using environmental preservation approach, so that appropriate coastal resource management policies can be implemented.

Keywords : fisheries resources; Pangkalpinang; tin mining

\section{Penulis Korespondensi}

Siti Aisyah | sitiaisyahsa057@gmail.com

\section{PENDAHULUAN}

Wilayah Kepulauan Bangka Belitung memiliki potensi timah yang cukup besar baik di darat, sungai dan laut. Potensi ini telah dimanfaatkan sejak ratusan tahun lalu dan menjadi salah satu penghasil devisa yang besar bagi Indonesia. Namun kegiatan mayoritas penambangan timah yang dilakukan di Provinsi Kepulauan Bangka Belitung ini tanpa ijin atau ilegal dan diindikasikan merupakan penyebab munculnya berbagai kerusakan lingkungan khususnya di kawasan laut yang dapat menimbulkan sedimentasi dan kerusakan ekosistem. Sebagaimana diketahui untuk melakukan kegiatan penambangan di Indonesia harus memiliki Izin Usaha Pertambangan (IUP) yang diajukan oleh badan usaha, koperasi atau perorangan.

Salah satu lokasi penambangan timah yang menjadi kajian dalam penelitian ini yaitu lokasi perairan Kota Pangkalpinang. Sebagai ibukota provinsi, Kota Pangkalpinang merupakan daerah yang strategis, terutama dalam kaitannya dengan pembangunan nasional dan pembangunan Provinsi Kepulauan Bangka Belitung. Wilayah pesisir dan perairan Kota Pangkalpinang tidak hanya menjadi sumber eksploitasi penambangan timah laut saja namun berbagai pemanfaatan sumberdaya dilakukan di wilayah tersebut, terutama kegiatan perikanan tangkap oleh nelayan.

Konsep pemanfaatan perlu memperhatikan keterpaduan berbagai macam kegiatan, sehingga pemanfaatan ganda wilayah pesisir yang terpadu dan serasi dapat berjalan untuk jangka waktu tertentu (Prianto dan Husnah 2009). Ditinjau dari sudut pandang persaingan antara nelayan dalam kegiatan penangkapan ikan dan para penambang timah di laut, masalah penting dalam pemanfaatan sumberdaya pesisir adalah ketidakseimbangan pemanfaatan sumberdaya tersebut, sehingga berpotensi menimbulkan konflik. Penelitian ini memiliki tujuan untuk 
mengetahui dampak penambangan timah di laut dan rekomendasi kebijakan pengelolaan sumberdaya yang tepat di Perairan Kota Pangkalpinang Kepulauan Bangka Belitung.

\section{BAHAN DAN METODE}

Metode yang digunakan dalam penelitian ini adalah metode deskriptif kualitatif dengan metode survei. Data yang digunakan dalam penelitian ini meliputi data primer dan data sekunder. Data primer diperoleh secara langsung di daerah penelitian melalui wawancara langsung kepada nelayan dan pekerja tambang berdasarkan kuesioner. Data sekunder diperoleh dari kelurahan setempat, Dinas Kelautan dan Perikanan (DKP) Kota Pangkalpinang, Badan Pusat Statistik (BPS) Kota Pangkalpinang, Bappeda Kota Pangkalpinang dan literatur penting lainnya, seperti jurnal dan laporan hasil penelitian.

$$
\text { Metode }
$$

pengambilan sampel/responden yang digunakan adalah teknik sampling purposive. Metode ini dilakukan dengan pemilihan sampel/responden berdasarkan pada karakteristik tertentu yang telah ditentukan sebelumnya (Nazir 1988). Populasi dalam penelitian ini adalah masyarakat (nelayan pemilik yang mewakili sifat-sifat dari keseluruhan nelayan yang menangkap ikan dan pengunjung pantai) yang memperoleh dampak langsung dari kegiatan penambangan timah di laut, serta penambang timah, dengan perbandingan persentase yang sama.

Jumlah contoh yang representatif menggunakan formula sebagai berikut (Fahrudin dan Adrianto 2007):

$$
\mathrm{n} \geq \mathrm{pq}\left(\frac{Z_{1 / 2 \alpha}}{b}\right)^{2}
$$

Dimana:

$\mathrm{n}=$ Jumlah contoh yang akan diukur $\mathrm{p}=$ Proporsi kelompok yang akan diambil contohnya

$q=$ Proporsi sisa dalam populasi contoh

$Z=$ Nilai tabel $Z$ dari $1 / 2 \alpha$ dimana jika $\alpha=0,05$ maka $Z=1,96$ atau jika $\alpha=0.1$ maka $Z=2,58$ (bisa dilihat pada tabel Z)

$\mathrm{b}=$ Persentase perkiraan kemungkinan kesalahan dalam menentukan ukuran contoh.

Analisis konflik dilakukan menggunakan pendekatan tahap konflik meliputi: a) prakonflik, yakni periode dimana terdapat ketidaksesuaian sasaran diantara dua pihak atau lebih; b) konfrontasi, yakni keadaan dimana konflik menjadi semakin terbuka; c) krisis, yakni periode puncak konflik, ketika ketegangan dan atau kekerasan terjadi paling hebat; d) akibat, yakni kedua belah pihak mungkin setuju untuk melakukan perundingan; e) pasca konflik, yakni situasi diselesaikan, ketegangan berkurang dan hubungan mengarah kepada kondisi normal diantara kedua belah pihak. 
HASIL DAN PEMBAHASAN

Berdasarkan Undang-Undang

Nomor 27 Tahun 2000, Kota Pangkalpinang ditetapkan sebagai Ibukota Provinsi Kepulauan Bangka Belitung dan merupakan provinsi ke-31 Republik Indonesia. Berdasarkan PP Nomor 79 Tahun 2007, Kota Pangkalpinang merupakan salah satu daerah otonomi yang letaknya di bagian timur Pulau Bangka dan berada pada garis $106^{\circ} 4^{\prime}$ sampai dengan $106^{\circ} 7^{\prime}$ Bujur Timur dan garis $2^{\circ} 4^{\prime}$ sampai dengan $2^{\circ} 10^{\prime}$ Lintang Selatan dengan luas daerah seluruhnya $118,40 \mathrm{~km}^{2}$. Kota Pangkalpinang yang berkedudukan sebagai ibukota provinsi memiliki fungsi sebagai pusat pengembangan wilayah yang meliputi: pusat pemerintahan, pusat perdagangan dan industri, pusat kegiatan politik, pusat pelayanan sosial seperti pendidikan, kesehatan, kesejahteraan sosial, pusat distribusi barang dan jasa, pusat kantor kegiatan penambangan timah serta pusat lembaga keuangan (Pemkot

Pangkalpinang 2016).

Kota Pangkalpinang memiliki potensi perikanan tangkap yang cukup prospektif. Hal ini dikarenakan secara geografis posisi Kota Pangkalpinang berada dekat dengan perairan. Kegiatan penangkapan ikan di Kota Pangkalpinang sebagian besar didominasi oleh nelayan usaha kecil dengan alat tangkap berupa perahu tanpa motor, perahu dengan motor tempel dan kapal motor terdaftar dengan bobot kurang dari 5 GT hingga 50 GT. Penduduk Kota Pangkalpinang yang berprofesi sebagai nelayan hingga tahun 2014 sebesar 1,97 \% dari total jumlah penduduk (Pemkot Pangkalpinang 2016). Hasil penelitian menunjukkan, rata-rata nelayan Pangkalpinang menggunakan kapal dengan ukuran kurang dari 5 GT (Gambar 1). Nelayan Kota Pangkalpinang sebagian besar berada di wilayah Kecamatan Bukit Intan yang tersebar diberbagai kelurahan,

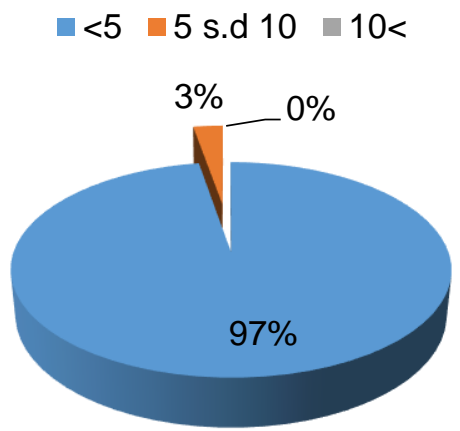

Gambar 1. Ukuran Kapal (GT) yang Digunakan oleh Nelayan Kota Pangkalpinang 
terutama Kelurahan Sinar Bulan dan Kelurahan Temberan yang letaknya berada di dekat pesisir.

\section{Analisis Konflik Pemanfaatan Sumberdaya Pesisir}

Terdapat 4 (empat) isu utama dalam analisis konflik pemanfataan sumberdaya pesisir meliputi 1) isu lingkungan; 2) isu pelanggaran hukum (penertiban penambangan ilegal); 3 ) isu sosial dan 4) isu ekonomi.

\section{Isu Lingkungan}

Wilayah pesisir yang meliputi daratan dan perairan pesisir sangat penting artinya bagi bangsa dan ekonomi Indonesia. Wilayah ini bukan hanya sumber pangan yang diusahakan melalui kegiatan perikanan dan pertanian, tetapi merupakan bagian dari lokasi bermacam sumberdaya alam, seperti mineral, gas dan minyak bumi, yang dapat dimanfaatkan untuk kesejahteraan manusia. Masalah penting dalam pemanfaatan sumberdaya pesisir adalah ketidakseimbangan pemanfaatan sumberdaya tersebut, ditinjau dari persaingan antara nelayan dalam kegiatan penangkapan ikan dan para penambang timah di laut. Tidak dipungkiri bahwa kegiatan yang dilakukan dengan memanfaatkan lingkungan dapat berdampak pada lingkungan itu sendiri. Kegiatan perikanan tangkap misalnya, jika dilakukan dengan menggunakan alat tangkap yang tidak ramah lingkungan dapat merusak terumbu karang sebagai habitat ikan karang. Sama halnya

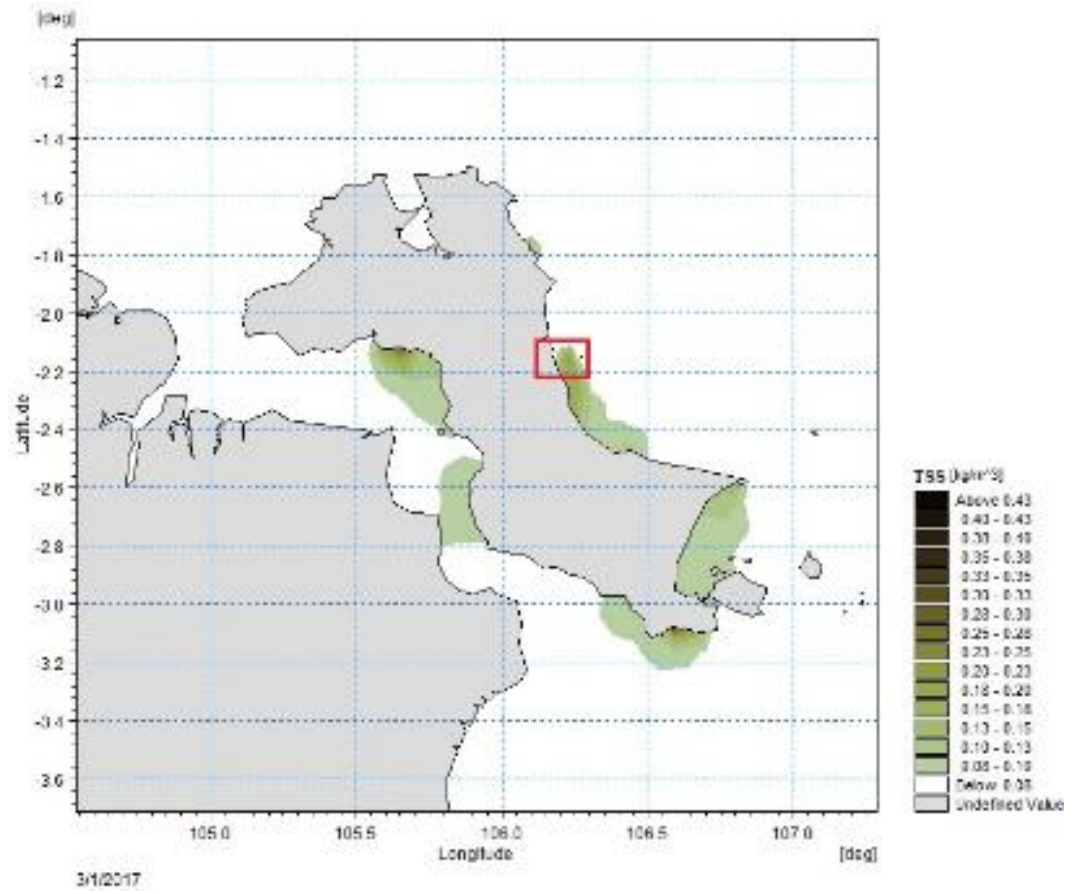

Gambar 2. Nilai Total Suspended Solid (TSS) di Perairan Pulau Bangka 
dengan kegiatan penambangan laut yang dapat menyebabkan sedimentasi sehingga habitat ikan semakin jauh ke laut lepas dan menyebabkan nelayan semakin jauh untuk melakukan penangkapan ikan.

Hasil pengambilan data lapangan pada responden nelayan dan penambang timah di Pangkalpinang menunjukan bahwa terdapat persepsi kondisi perairan sudah mulai tercemar yang sebagian besar disebabkan oleh dampak dari penambangan timah ilegal di laut yang berada di perairan Kota Pangkalpinang sehingga berpengaruh terhadap penangkapan ikan bagi nelayan Kota Pangkalpinang. Hal ini selaras dengan hasil pengolahan data pemodelan dampak penambangan timah terhadap nilai Total Suspended Solid (TSS) di perairan Kota Pangkalpinang 0.20-0.23 kg. $\mathrm{m}^{-3}$ (Gambar 2).

$$
\text { Prianto dan Husnah }
$$
menjelaskan bahwa sedimentasi yang tinggi di wilayah pesisir telah menyebabkan terjadinya perubahan bentang alam di daerah pantai. Hal ini disebabkan adanya penambangan timah di sepanjang pantai Pulau Bangka. Tingginya aktivitas penambangan di sepanjang pantai telah menyebabkan pada beberapa bagian terjadi proses pendalaman akibat pengambilan tanah dasar laut dan pada bagian lain terjadi penumpukkan butiran tanah.

Dampak penimbunan oleh sedimen (sedimentasi) yang terjadi di perairan baik secara langsung maupun tidak langsung berhubungan dengan keberadaaan keanekaragaman hayati. Penimbunan sedimen di dasar perairan dapat merusak dan memusnahkan komunitas hewan bentik dan lokasi pemijahan biota perairan lainnya. Partikel tanah yang tersuspensi akan menutupi habitat (tanaman air, permukaan tanah) dan telur-telur seluruh biota perairan, sehingga telur tidak dapat berkembang dengan baik. Lambat laun akan terjadi penurunan populasi secara masal yang akhirnya dalam jangka panjang dapat menurunkan keanekaragaman hayati perairan (Prianto dan Husnah 2009).

Isu Pelanggaran Hukum (Penertiban Penambangan llegal)

Keberadaan timah sebagai
komoditas sumber daya yang
mempesona tentunya akan mampu
memberikan keuntungan dan menjadi
ajang perebutan bagi berbagai aktor
untuk menikmati keuntungan tersebut.
Tidak menutup peluang, masyarakat
yang berada di Pangkalpinang pun
berupaya mengeruk keuntungan dari
timah tersebut, namun tidak sedikit
dilakukan dengan jalan penambangan
tanpa ijin atau ilegal. Dikutip dari
Antaranews.com (2019) Pemerintah
Kota Pangkalpinang, Provinsi Kepulauan


Bangka Belitung menertibkan dan membakar tambang bijih timah ilegal yang beroperasi di alur Sungai Rangkui, karena melanggar aturan dan meresahkan wilayah tersebut. Walikota Pangkalpinang menegaskan untuk menindak tegas seluruh penambangan ilegal yang beroperasi di wilayah kota Pangkalpinang. Pemerintah Kota Pangkalpinang bekerja sama dengan TNI dan Polri untuk memberantas penambangan bijih timah ilegal yang meresahkan masyarakat, merusak lingkungan dan menambah potensi terjadinya bencana alam di daerah Pangkalpinang.

Walikota

Pangkalpinang memimpin langsung setiap upaya penertiban penambangan ilegal di Pangkalpinang untuk mengantisipasi kebocoran informasi saat dilakukan sidak dan penertiban. Hal ini dilakukan sebagai penegasan bahwa di wilayah Pangkalpinang tidak ada pertambangan timah di laut. Hasil sidak memperlihatkan bahwa penambang di Pangkalpinang bukanlah warga setempat melainkan kebanyakan warga yang berasal dari luar Pangkalpinang (Kumparan.com 2019).

Menurut Murty dan Yuningsih (2017), tambang timah ilegal semakin marak sejak dikeluarkannya SK Menperindag nomor 144/MPP/Kep/4/1999 tanggal 22 April 1999 bahwa Timah dikategorikan sebagai barang bebas (tidak diawasi) dan pencabutan status timah sebagai komoditas stategis, sehingga tidak dimonopoli lagi oleh satu BUMN dan dapat diekspor secara bebas oleh siapapun. SK Memperindag tersebut menyebabkan maraknya kegiatan penambangan timah ilegal, sehingga Pemerintah perlu menciptakan beberapa peraturan perundang-undangan sebagai upaya mengantisipasi pelanggaran maupun tindak pidana di bidang pertambangan, khususnya pertambangan timah. Peraturan yang telah dibuat oleh Pemerintah Provinsi Kepulauan Bangka Belitung dalam rangka menanggulangi pertambangan timah ilegal ini adalah Peraturan Daerah No. 7 Tahun 2014 tentang Pengelolaan Pertambangan Mineral. Pemerintah Pusat juga telah mengeluarkan undangundang yang mengatur mengenai Pertambangan Timah ini, melalui Undang-Undang Nomor 4 Tahun 2009 tentang Pertambangan Mineral dan Batubara.

\section{Isu Sosial}

Isu sosial yang terjadi dalam konflik pemanfaatan sumberdaya pesisir dalam penelitian ini diperoleh dua sumber utama yang saling berperan, yakni para penambang timah di laut dan nelayan perikanan tangkap. Hasil penelitian lapangan di Kota Pangkalpinang 


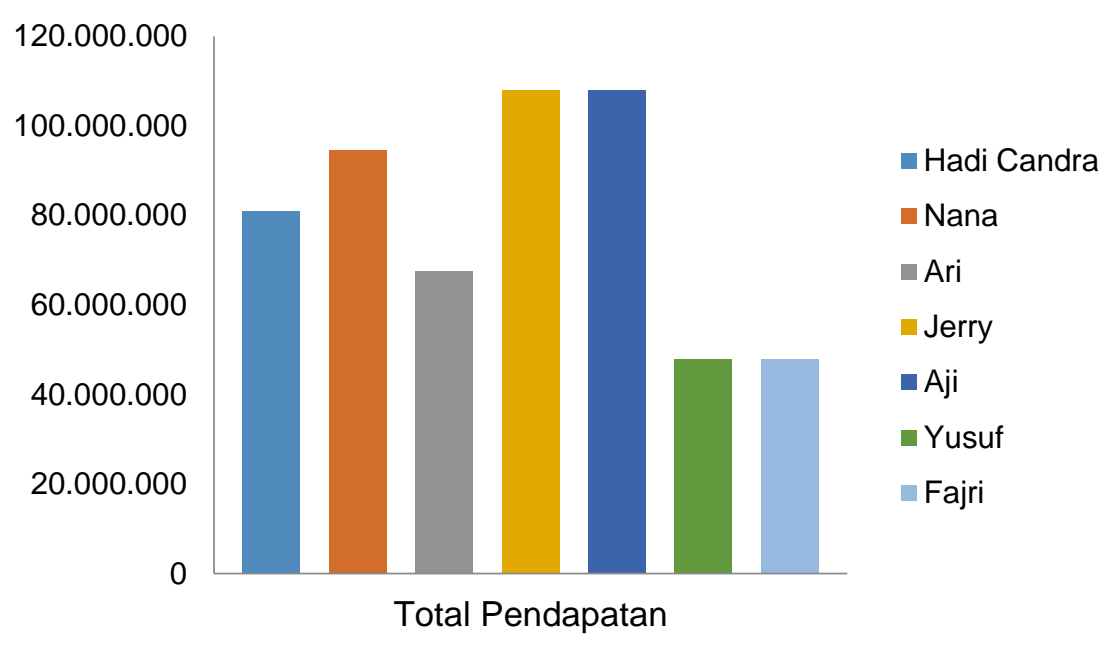

Gambar 3. Pendapatan Penambang Timah

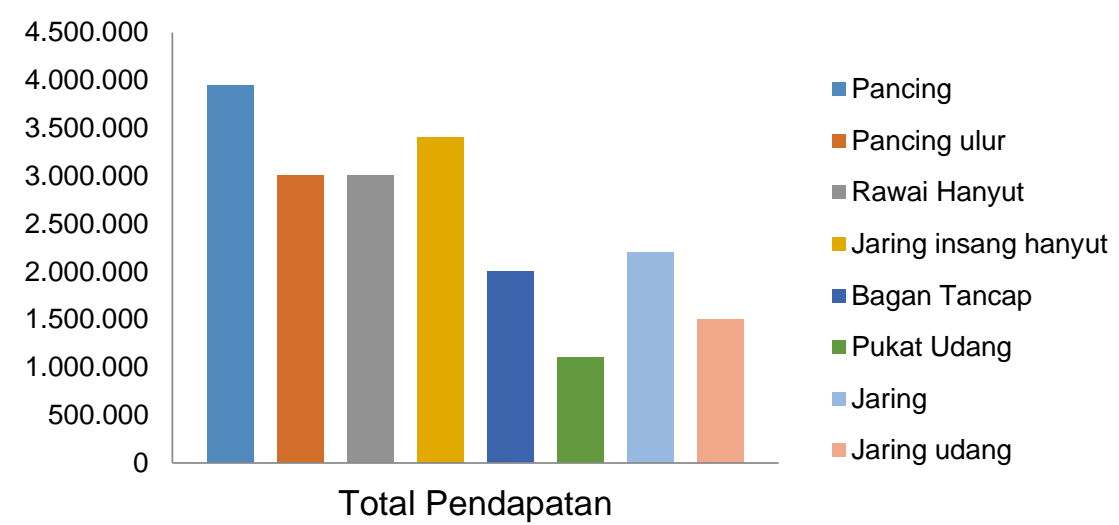

Gambar 4. Pendapatan Nelayan Kota Pangkalpinang

menunjukkan terdapat isu sosial yang cukup menonjol. Salah satu contohnya kasus yang terjadi di Kelurahan Sinar Bulan, Kota Pangkalpinang. Ketua Kelompok Nelayan di lokasi tersebut selain berprofesi sebagai nelayan, berprofesi juga sebagai penambang timah ilegal dan memanfaatkan status nelayannya untuk memperoleh harga solar bersubsidi untuk keperluan penambangan. Hal tersebut menimbulkan potensi konflik sosial bagi nelayan lainnya yang berprofesi penuh sebagai penangkap ikan. Sehingga kejadian ini menyebabkan tidak sedikit nelayan dan penambang timah di kelurahan tersebut saling bersinggungan.

Permasalahan penambangan timah di Pulau Bangka saat ini merupakan fenomena gunung es yang suatu saat dapat meledak dan menjadi masalah sosial yang berujung konflik dengan masyarakat lainnya. Baik dalam 
perebutan pemanfaatan sumberdaya pesisir maupun seperti kasus yang terjadi di Kelurahan Sinar Bulan tersebut.

\section{Isu Ekonomi}

Tidak dapat dipungkiri bahwa timah sudah menjadi bagian vital bagi masyarakat Kepulauan Bangka Belitung. Jika dihentikan secara mendadak, dapat memungkinkan terjadinya kegoyahan di dalam perekonomian daerah. Sebagian besar masyakarat Kepulauan Bangka Belitung yang bermata pencaharian sebagai penambang saat ini hampir tidak bisa lepas dari kegiatan menambang timah. Walaupun potensi lainnya cukup menggiurkan seperti perikanan tangkap dan pengolahan hasil perikanan, namun pendapatan tersebut jauh lebih rendah dari hasil pendapatan timah yang bisa mencapai ratusan juta per bulan. Hasil pengambilan data responden penambang timah di lapangan memperlihatkan rata-rata penghasilan yang diperoleh dimulai dari 40 - 100 juta perbulan (Gambar 3), di mana status usaha terdiri dari kelompok, milik sendiri dan kerja dibawah orang lain "bos" dengan harga timah perkilogram bisa mencapai Rp. 90.000,--

Jauhnya perbedaan pendapatan antara nelayan dan penambang timah di Kota Pangkalpinang menyebabkan kegiatan penambangan timah sulit ditinggalkan oleh masyarakat, dan berpotensi membuat masyarakat lainnya berpindah profesi menjadi penambang. Hal ini terjadi di lokasi penelitian Kota Pangkalpinang area Tanjung Bunga dan Sinar Bulan dimana nelayan yang dijadikan responden memiliki pekerjaan sampingan sebagai penambang timah ilegal.

Walaupun potensi pendapatan dari aktivitas penambangan jauh lebih tinggi daripada aktivitas perikanan tangkap, jika dimasukkan variabel waktu di dalam perhitungan dan analisa pendapatan mereka, bisa saja pada titik waktu tertentu keadaan akan berbalik. Pendapatan para nelayan dapat jauh lebih tinggi dan terjamin daripada penambang. Hal ini disebabkan karena jumlah timah yang ada di dalam bumi bersifat terbatas dan tidak dapat diperbaharui sedangkan jumlah ikan yang ada di laut (asalkan diambil secara bijaksana) memberikan gambaran yang sebaliknya.

Hal lain juga yang perlu dipertimbangkan diantara kedua aktivitas ekonomi tersebut adalah besaran potensi kerusakan lingkungan yang dapat terjadi. Hal ini menjadi penting di dalam isu ekonomi tatkala jika kerusakan lingkungan tersebut sudah menimbulkan kerugian bagi masyarakat, contoh pencemaran dan sedimentasi hilir sungai akibat penambangan di hulu yang mengakibatkan banjir dan banyak ikan 
yang mati. Tentu saja di dalam pemulihan kondisi lingkungan ini akan mengeluarkan biaya-biaya yang seringkali tidak sedikit. Sehingga bisa jadi total keuntungan bersih setelah dikurangi total biaya yang dikeluarkan untuk pemulihan lingkungan, aktivitas penambangan dapat bahkan jauh lebih kecil dari penangkapan ikan. Perlu data dan analisis lebih jauh untuk pembuktiannya. evaluasi Ekonomi dan Analisis Biaya Manfaat mungkin dapat direkomendasikan dalam melakukan kajiannya, (Georgiou et al. 1997; Sukhdev et al. 2010; Tuan dan Tinh 2013).

\section{Analisis Resolusi Konflik}

Penurunan kualitas perairan (pencemaran) yang terjadi di Pulau Bangka, menunjukkan permasalahan yang cukup kompleks dan sulit dipahami jika hanya menggunakan satu disiplin keilmuan. Pendekatan sistem, merupakan cara penyelesaian persoalan yang dimulai dengan dilakukannya identifikasi terhadap sejumlah kebutuhan, sehingga dapat menghasilkan suatu operasi sistem yang efektif. Dengan pendekatan sistem dalam membangun teknik pengendalian pencemarannya dalam upaya mewujudkan perairan umum yang bersih dan lestari, sehingga pemanfaatan fungsinya dapat berkesinambungan.
Upaya pengelolaan terhadap perairan di Pulau Bangka sudah sangat mendesak. Menyikapi hal ini diperlukan koordinasi antara pemerintah daerah dengan masyarakat dalam upaya merehabilitasi ekosistem perairan. Keterlibatan masyarakat sangat diperlukan, karena penambangan timah illegal dan inkonvesional yang berkembang sebagian besar dilakukan oleh masyarakat awam. Pemerintah sebagai pengambil keputusan mensinergikan berbagai komponen lainnya seperti swasta, perguruan tinggi, dan lembaga swadaya masyarakat (LSM) untuk menyelesaikan permasalahan ini. Sehingga permasalahan penambangan timah inkonvensional ini dapat memiliki solusi yang baik dan memenuhi persyaratan perundang-undangan tentang pertambangan yang berlaku.

Menurut Prianto dan Husnah (2009), pendekatan yang diterapkan dalam upaya pengelolaan tambang timah di Pulau Bangka mengandung unsur-unsur akomodatif, suportif, protektif, dan antisipatif. Akomodatif berarti bahwa pengelolaan kawasan mampu mengakomodasi kepentingan masyarakat luas tanpa merugikan pihak lain. Suportif berarti mampu mendorong pembangunan dan menjaga kelestarian sumber daya alam terutama ekosistem perairan. Protektif berarti mampu 
melindungi sumber daya yang secara ekologis sangat penting dan aspekaspek lingkungan fisik lainnya. Antisipatif berarti mampu mengatasi konflik dalam pemanfaatan ruang. Yunianto (2009) mengungkapkan pendapat lain, dalam rangka menyelesaikan permasalahan pertambangan timah di Propinsi Kepulauan Bangka Belitung diperlukan harmonisasi dan sinkronisasi kebijakan lintas sektoral dan di berbagai tingkatan pemerintahan.

\section{Kebijakan Pengelolaan Sumberdaya Pesisir yang Tepat}

Berbagai isu-isu dan permasalahan yang muncul dalam pengelolaan sumberdaya pesisir, dibutuhkan suatu model pengelolaan yang kolaboratif yang memadukan antara unsur masyarakat pengguna (seperti kelompok nelayan, pengusaha perikanan, penambang di laut jika kaitannya dengan kasus di Pulau Bangka) dan pemerintah yang dikenal dengan Co-management. Model pengelolaan ini berusaha menghindari peran dominan yang berlebihan dari satu pihak dalam pengelolaan sumberdaya pesisir dan laut sehingga pembiasaan aspirasi pada satu pihak dapat dihindari. Melalui model ini pula, pengelolaan sumberdaya pesisir dan laut dilaksanakan dengan menyatukan lembaga-lembaga terkait terutama masyarakat dan pemerintah serta stakeholder lainnya dalam setiap proses pengelolaan sumberdaya, mulai dari perencanaan, pelaksanaan, pemanfaatan dan pengawasan. Susunan dalam model pengelolaan ini bukanlah sebuah struktur legal yang statis terhadap hak dan aturan, melainkan sebuah proses yang dinamis dalam menciptakan sebuah struktur lembaga yang baru.

Dalam jangka panjang, pelaksanaan Co-management ini diyakini akan memberikan perubahanperubahan ke arah yang lebih baik yaitu:

1. Meningkatkan kesadaran masyarakat akan pentingnya sumberdaya pesisir dan laut dalam menunjang kehidupan.

2. Meningkatkan kemampuan masyarakat, sehingga mampu berperan serta dalam setiap tahapan pengelolaan secara terpadu.

3. Meningkatkan pendapatan masyarakat dengan bentukbentuk pemanfaatan yang lestari dan berkelanjutan serta berwawasan lingkungan.

Keberhasilan pengelolaan dengan model Co-management ini sangat dipengaruhi oleh kemauan pemerintah untuk mendesentralisasikan tanggung jawab dan wewenang dalam pengelolaan kepada nelayan dan 
stakeholder lainnya. Oleh karena Comanagement membutuhkan dukungan secara legal maupun finansial seperti formulasi kebijakan yang mendukung ke arah Co-management, mengijinkan dan mendukung nelayan dan masyarakat pesisir untuk mengelola dan melakukan restrukturisasi peran para pelaku pengelolaan perikanan. Pengelolaan $\mathrm{Co}$ management menggabungkan antara pengelolaan sumberdaya yang sentralistis yang selama ini banyak dilakukan oleh pemerintah (government based management) dengan pengelolaan sumberdaya yang berbasis masyarakat (Rudyanto 2004).

\section{SIMPULAN DAN SARAN}

1. Analisis konflik pemanfataan sumberdaya pesisir terdiri dari empat isu utama meliputi 1) isu lingkungan yang menunjukan bahwa kondisi perairan yang sudah mulai tercemar dan sebagian besar disebabkan oleh dampak dari penambangan timah ilegal di laut; 2) penertiban penambangan ilegal yang sering dilakukan oleh Pemerintah Kota Pangkalpinang yang bekerja sama dengan Polisi dan TNI sebagai bentuk dari penegakan aturan; 3) isu sosial layaknya fenomena gunung es yang suatu saat dapat meledak dan menjadi masalah sosial yang berujung konflik dengan masyarakat lainnya, terutama dalam perebutan pemanfaatan sumberdaya pesisir antara nelayan dan penambang timah di laut; dan 4) dari isu ekonomi, jauhnya perbedaan pendapatan antara nelayan dan penambang timah di Kota Pangkalpinang menyebabkan kegiatan penambangan timah sulit ditinggalkan oleh masyarakat, dan berpotensi membuat masyarakat lainnya berpindah profesi menjadi penambang;

2. Resolusi konflik dilakukan secara harmoni antara pemerintah, masyarakat, swasta, perguruan tinggi dan LSM dengan pendekatan pemahaman kepentingan pelestarian lingkungan;

3. Kebijakan pengelolaan sumberdaya pesisir yang tepat dengan model pengelolaan yang kolaboratif yang memadukan antara unsur masyarakat pengguna dan pemerintah yang dikenal dengan Co-management yang menghindari peran dominan yang berlebihan dari satu pihak dalam pengelolaan sumberdaya pesisir dan laut.

\section{PERSANTUNAN}

Peneliti mengucapkan terima kasih atas kerjasama penelitian dengan Conservation Strategy Fund (CSF), 
Kelurahan Temberan, nelayan dan penambang timah di Kota

Pangkalpinang. Penelitian ini terselenggara juga dengan dukungan dari The David and Lucille Packard Foundation.

\section{DAFTAR PUSTAKA}

Antaranews.com. 2019. "Pemkot Pangkalpinang Bakar Tambang llegal." Diambil 11 Juli 2019 (https://www.antaranews.com/berit a/928508/pemkot-pangkalpinangbakar-tambang-ilegal).

Fahrudin, Akhmad dan Luky Adrianto. 2007. "Pendekatan Langsung Dengan Contingent Valuation Method. Modul disampaikan pada Kegiatan Pelatihan Teknik dan Metode Pengumpulan Data Valuasi Ekonomi. Bogor."

Georgiou, Stavros, Dale Whittington, David Pearce, dan Dominic Moran. 1997. Economic values and the environment in the developing world. Cheltenham (GB): Edward Elgar Publishing Ltd.

Kumparan.com. 2019. "Walikota Pangkalpinang Tertibkan Tambang llegal." Diambil 11 Juli 2019 (https://kumparan.com/babelhits/w alikota-pangkalpinang-tertibkantambang-ilegal-1rGoaQCXHFO). Murty, Theta dan Henny Yuningsih. 2017. “Upaya Penegakan Hukum
Pidana Terhadap Tindak Pidana Penambangan Timah llegal di Provinsi Bangka Belitung." Simbur Cahaya 24(1 Jan 2017):4348-74.

Nazir, Moh. 1988. Metode Penelitian. Jakarta (ID): Ghalia Indonesia.

Pemkot Pangkalpinang. 2016. "Profil Kota Pangkalpinang Tahun 2016: Potensi dan Peluang." Diambil 11 Juli 2019

(https://www.pangkalpinangkota.g

o.id/profil-kota-pangkalpinang2016/).

Prianto, Eko dan Husnah Husnah. 2009.

"Penambangan

Timah

Inkonvesional: Dampaknya terhadap Kerusakan Biodiversitas Perairan Umum di Pulau Bangka." BAWAL Widya Riset Perikanan Tangkap 2(5):193-98.

Rudyanto, Arifin. 2004. "Kerangka Kerjasama dalam Pengelolaan Sumberdaya Pesisir dan Laut." Makalah Disampaikan pada Sosialisasi Nasional Program MFCDP.

Sukhdev, Pavan, Heidi Wittmer, Christoph Schröter-Schlaack, Carsten Nesshöver, Joshua Bishop, P. ten Brink, Haripriya Gundimeda, Pushpam Kumar, dan Ben Simmons. 2010. The economics of ecosystems and biodiversity: mainstreaming the 
economics of nature: a synthesis of the approach, conclusions and recommendations of TEEB. UNEP, Ginebra (Suiza).

Tuan, Tran Huu dan Bui Duc Tinh. 2013. Cost-Benefit Analysis of Mangrove Restoration in Thi Nai Lagoon, Quy Nhon City, Vietnam. IIED.
Yunianto, Bambang. 2009. "Kajian Problema Pertambangan Timah di Propinsi Kepulauan Bangka Belitung Sebagai Masukan Kebijakan Pertimahan Nasional." Jurnal Teknologi Mineral dan Batubara 5(3):97-113. 